Władysław B. Kubiak, Władysław Żakowski

\title{
FARAFRA. A PRELIMINARY SURVEY OF THE HISTORICAL EVIDENCE
}

The present bird's-eye view of the Farafra Oasis past neither pretends to be detailed nor complete. The authors have no such intention. Besides, this would not be a proper place for extensive historical elaboration. It simply seems opportune and useful while a number of articles focusing on the present trends of local development are published to introduce also a short historical overview.

\section{PREHISTORIC PERIOD}

Natural features of the Farafra Depression, its climate, wealth of water resources, relative fertility of its soil, all should allegedly favour a very ancient human presence in the region. Yet practically next to nothing is known about its prehistoric past; no trace of early population came so far to light, a curious fact due rather to the lack of systematic research then to its total absence. In other parts of the western Sahara, especially in the northern Sudan, where extensive surveys were carried on, remains of Palaeolithic man are not lacking. Hopefully, investigations just commenced in Farafra by such scholars as B. Barich, H. Fekri and A. Kuhlmann (oral communication of prof. L. Krzyżaniak) will improve our knowledge in the field.

\section{PHARAONIC PERIOD}

The name of Farafra: Ta ahut, Ta iht, Ta ihw of the hieroglyphic texts or still more precisely transcribed, had been recorded many times. For first time in the text of the 5th Dynasty (ca. 2500-2400 B.C.). The meaning of the name is "the Land of the Cow" or "the Land of the Cows", which is probably connected with the cult of Hathor. With the present day Oasis of Farafra it was identified only thanks to the text preserved on the Karnak Temple inscription describing the Libyan invasion of Egypt at the time of king 
Merenptah of the 19th Dynasty who ruled from 1223 to 1211 B.C. This allows a rather elaborate reconstruction of the Libyan Armies' itinerary: One of them which took the southern desert route crossed to Baharia and then probably occupied Farafra before proceeding to Upper Egypt and the seat of the Kingdom in Thebes (Brugsch 1878, Fakhry 1976). Later on the inscription from Edfu (Sethe 1927) and Ptolemaic texts (Wagner 1987) fully confirmed this identification since then generally accepted by Egyptologists. It is, however, fairly strange that all references to this Oasis were recorded in the inscriptions and papyri from the Nile Valley; no remains from the Pharaonic period, let alone the written evidence, have been found so far in the Farafra Depression itself. And yet numerous mentions in the hieroglyphic texts (Gautier 1925) prove the close relations between the Valley of the Nile and the Oasis. There certainly were frequent contacts either through Baharia which together with Farafra was part of the Oxyrhynchite Nome in the Ptolomaic period or using the route by Dakhla (ancient Kenemet) to Kharga and farther on to Thebaid on which the Greater Oases (Dakhla and Kharga) depended.

The location of Farafra on the western border of Egypt's frontier area with unquestionably great strategic value for the country's defence against the warlike Libyan nomads would rather preclude long-time independence from Egypt which some scholars suggest (cf. Bliss 1983 for further references). In our opinion it certainly was part of the Egyptian Empire since the early dynastic period. The written evidence seems to support this opinion but the lack of material vestiges in its territory, so strikingly contrasting with the wealth of architectural and epigraphic finds in the remaining oases, is either purely accidental or rather due to inadequate archaeological research works hardly ever conducted. Practically, the only archaeologist so far seriously interested in Farafra was Ahmad Fakhry and even he himself never had an opportunity to conduct systematic excavations there or to spend in the area more than two days at a stretch. In all probability, and this was also Fakhry's hope (1974), future investigations will bring expected discoveries.

The hieroglyphic references to Farafra are usually the short ones, without extensive contexts which would have brought more information on the Oasis in the Pharaonic times. In addition to the Karnak inscription concerning the Libyan attack referred to above and short mentions which might be in the connection with a tribute paid by the Oasis, there are only two texts including some information on Farafra's economy. One of them is a famous story of the so-called Eloquent Peasant who visited the court of Hieracleopolis during the reign of Khety III, king of the 10th Dynasty (21st century B.C.). In the papyrus there is a list of articles the peasant brought with him, evidently for trafficking. According to the text, such articles were brought from Farafra as reed, rush, natron, salt and branches of "avent" an unidentified tree. From salt fields which in all probability should be 
equivalent to the present-day Wadi el-Natrun, leopard hides, wolfs tails, wild menth, pigeons, partridges, quails, anemons, narcissuses, fruits and other good things were brought (Roeder 1927). There probably is a certain confusion as to the places of origin of two groups of articles. From what we know about both places the list should rather be reversed; the first part of the lists (reeds, rush and natron) fits Wadi el-Natrun products better than Farafra's and vice versa.

Another text where Farafra is mentioned is the Karnak list of Mines which dates from the reign of Rameses II (Miller 1906-20). Unfortunately, the inscription does not specify kinds of minerals the mines produced. Fakhry advances a suggestion that it was iron ore (pyrite, marcasite) common in the Farafra Depression (1974, p.158). It is possible, but more likely it would be Alum and a kind of mineral vitriol, commodities mentioned by the Arabic sources, common not only in Farafra but in the other oases as well (Al-Ya'qubi-Wiet 1937; Al-Bakri 1965).

\section{THE GRECO-ROMAN PERIOD}

Historical evidence concerning Farafra in the Classical Period at first sight appears in the even more dim light then its more ancient past. It has even been declared recently (in the remarkable and very detailed study on the Egyptian Oases in the Greco-Roman times by G. Wagner 1987) that "nous ne savons rien de l'Oasis de Farafra greco-romain pas même son nom". From the viewpoint of the documentary basis of Wagner's study, which focuses on the main Greek papyri and inscriptions, it might be true. But the written documents are not the only historical evidence. Wagner himself, a few lines farther in the same paragraph, as if to contradict his previous statement, draws attention (after Fakhry) to the remains of several architectural objects, apparently of Roman and Byzantine date, situated near the Farafra village. He leaves them, however, without even a shortest comment. Fakhry, by the way, in his last volume, published already after his death (1974), mentions a few more vestiges from the same period. He also reminds Cailliaud's map of the early 19th century where he marked some ancient tombs otherwise unrecorded. There are, moreover, two other localities in the Depression surveyed by Fakhry: 'Ain al-Wadi and 'Ain Dalla, distant from the Farafra village (45 and $75 \mathrm{~km}$ respectively), where important traces of the occupation in the Roman and Byzantine times were found (1974). No doubt they were parts of the outer Farafra territory, connected with it and not with much more distant oases of Baharia or Dakhla.

The archaeological evidence collected by Fakhry (1974) is not the only one available. A systematic study of the 19th- and early 20th-century travellers' accounts brings more relevant, although not always reliable and 
scientifically dated material, especially concerning allegedly Roman hydraulic constructions. Yet, because of the limited space of this article we have to leave all these details outside the scope of the present outline and limit the discussion. But the occasion calls for a more general observation: a nearly total want of documentary material at Farafra, especially striking when confronted with the wealth of written sources in the other three oases, coupled with our ignorance of its Greco-Roman name which precludes the use of external information, ostensibly leaves a scholar without tools for reconstruction of its past and historical characteristics. Archaeological vestiges so far never systematically studied hardly improve the situation. But this is only one aspect of the problem. The second is that Farafra, just as the other oases, although nameless (the names such as Porphyrion used by de Slane, apud al-Bakri, 1965; or Trynitheos, found in Despois, Enc. Isl. II Ed., are purely hypothetical), was a concrete historical and socio-geographical unit. After all, it is not the volume of contemporary written evidence but its bio-environmental and social reality, its spatial location, inter-oasis communication and general historical context that determine geo-political and economic factors.

Farafra, one of four oases, by the desert standards situated not very far away from the Nile Valley, is the most distant one. Yet it was only a 4 days' journey by a camel caravan either to Baharia, i.e. the Lesser Mikra - Oasis or to Dakhla - the Great - Megale - Oasis, by the route which connected the two and crossed Farafra. The contacts must have been frequent, especially that it would be difficult to by-pass it unless using a roundabout way via the desert and the Nile Valley.

There is no reason whatsoever why Farafra should not be the integral part of the oasite entity of similar ethnic composition, socio-economic structure and administrative organization. Therefore, well-established facts by the long-lasting research, especially by generations of papyrologists: social, economic, administrative etc., concerning the other oases can by inference and comparison, at least in part, be attributed to Farafra as well.

We are giving below a summary of the most important facts, collected mainly by Wagner (1987), but first let us discuss the alleged administrative adherence of Farafra to either of the group of oases.

Prevalent opinion among scholars is that Farafra was historically connected with Baharia. In the modern times it was mainly based on its social resemblance to the latter (Fakhry 1973) in the past because in the Ptolemaic Period it (together with Baharia), belonged to the Oxyrhynchite Nome. But later the situation had evidently changed. It is clearly shown by an information in one of the oldest Arabic geographical works Kitab alBuldan by al-Ya'qubi, an author of the 9th century, and the first Arabic source mentioning Farafra by name. The text runs as follows: "From Abshaya (town proceeding later medieval and present-day Balyana) one goes to the Oases through the desert and barren mountains six days. First 
one arrives in the Outer Oasis (Kharga)... Farther there are the Inner Oasis (Dakhla) with the chief town Farfaran inhabited by the people of all descent: Egyptians and others" (Wiet's Transl. 1937).

We would not certainly suggest that Farafra, whatever its name, already in the Roman Period was a capital of the two Inner Oases, but the assurance of a very reliable author that it was so in his time gives no reason for doubt that it was regarded as the part of it. The information is of value also for the preceding period, especially as we know that the Arabs did not change the administrative division of Egypt of the pre-Islamic times until the middle Fatimid Period, i.e. until the 11th century A.D. Additional evidence for Farafra as being connected with Dakhla will be given below.

Administratively, the Oases in Roman times were divided into two "nomes": of the Greater Oasis, with the capital in Hibis, and the Lesser Oasis with the capital in Psobthis. On the higher echelon they depended on the province of Thebaid and Heptanomos. To the local capitals were subordinated all villages, the basic administrative units, of which some as chief places of toparchies were of higher status.

The administration was rather complicated and excessive. Formally stabilized, in practice it was frequently reformed. It was composed of hierarchy of civil servants, judicial functionaries, taxation clerks, temple clergy and military officers; the latter categories were probably less subservient to the head of civil administration (Strategos) but certainly acting in concert with him.

The population, doubtlessly of Libyan-Berber origin was highly Egyptianized and must have been fairly uniform but sufficiently distinct to be given the name of "Oasites".

The religion was of course paganism: the type of late Egypto-Hellenic syncretism, perhaps influenced by local beliefs. Christianity, probably introduced not much later than in Alexandria, must have added to the religious mosaic, especially as of early, it was a place of detention of troublesome early Christian clergy.

Security of the Oases was precarious in spite of the standing Roman garrizons in many places and the existing defences. Especially in the later period, when the power and military organization dwindled, the incursions of proto-Nubian, Beja and Libyan tribes such as Nobates, Blemmys and Marikes, became more and more frequent. In this respect, Farafra was probably more than the other Oases threatened by the incursions.

Economic life did not apparently differ from what we know of it in later times. The base of it was, of course, agriculture made possible by extensive irrigation with water from numerous local wells and natural sources. Wheat, barley and - to a lesser extent - millet were staple grains and a date palm was a chief fruit tree with olive-tree and vine as additional, the most popular cultures, to which cotton should be added. Of other products 
we hear of sesame, cardamom, and of course various vegetables. Camel, donkey and some poultry (mainly pigeons, fowl and geese) were raised.

Agricultural products were used for local consumption, exports, taxes in kind and some of them for small local industry of wine making, olive oil pressing and textiles. An important article of trade which was made a sort of a state monopoly was alum.

The extent of land under cultivation, volume of exported goods, number of inhabitants should obviously be for Farafra treated separately from the other oases although there is a little founding for that. The normal opinion among scholars is that Farafra was smaller and less important then the other oases. It might be true because the greater distance from the Nile Valley, more difficult transportation and hazards of the frontier areas could make existence harder than elsewhere. Yet it not necessarily should have been so. Natural conditions are here perhaps better then in other oases and cultivable land and water even more abundant. Perhaps future research will give a more rational answer to these questions.

\section{THE BYZANTINE PERIOD}

Historical information concerning the Christian period in Farafra in even less satisfactory than of the former centuries. Since, however, there never occurred a sharp breach from one period to another and there was a remarkable continuity in various fields of activity: administrative, judiciary, military, economic etc., much of our knowledge can be transferred to the successive period, certainly not without serious reservations.

That Farafra was Christian can be of little doubt. However scanty, the material remains: a metal cross, a Coptic inscription, Christian symbols painted in one of the tombs, all mentioned by Fakhry (1974), bear witness to the spread of the Christian creed. Even more telling is the information by a well-known author of the 11th century, el-Bekri that the population of numerous Farafran villages is Coptic Christian (el-Bekri 1965). Assuming that the information is roughly contemporaneous to his writing, assumption substantiated by his narrative concerning Baharia religious celebrations, it proves that Christianity must have been firmly rooted if it could survive for about 4 centuries since the Arab conquest. As regards the time of Christianization or the question whether Farafra was a place of banishment of the holy fathers or Arians, this must for the time being remain in the sphere of speculation. 
THE ARAB PERIOD

The Arabic, but certainly at first not Islamic period despite the local, oral traditions (Bliss 1983) commenced with the conquest of Egypt. When the Arab army detachments invaded the Oases we do not know. They were very early in Faiyum and already by 651 in Nubia which, however, was not conquered until many centuries later. It would be logical to assume that in planning the invasion of Nubia the Arabs would not have left unsubjugated the Oases on the flank, not far away from the Nile Valley with probably hostile, Christian population. But we doubt if the conquest meant at first much to the Oases. If even in the Nile Valley, the old local Coptic, partly Greek administration was left in place for about one century, the same must have been done in the Oases. It is also doubtful if a standing Arab garrizon was ever appointed there. At most, an occasional patrol was sent, especially at the time of collecting taxes or tribute, whichever it was at that time. But rapid Islamization and subjugation of unruly Berber, mainly nomadic, desert tribes, even if only temporary, could for a time improve security of the Oases and save them from the raids of the nomads.

We can assume that at first not much has changed it the life of Farafra and its inhabitants. From the short notice of al-Ya'kubi, already cited above we can draw conclusion that it was still a flourishing place, but perhaps slightly less so than its bigger sister Dakhla. The town of Farfaran, on the other hand, gained the leading position as a regional capital. Its population must have been strikingly diversified if it could deserve a special remark by al-Yakubi.

By the early 10th century something began to change. The change in the religious life must have been particularly important. The 10th-century geographer, al-Istakhri, in his short passus concerning the Oases, noted that not even a monk had remained there. The remark implied a change of a probably notorious situation when monks had been a commonplace. It certainly indicates the progressing Islamization of the Oases, but it can also reflect the political standing of the Oases. According to the famous traveller and historiographer of the 10th century, al-Mas'udi, at the time he composed his famous work Muruj al-Dhahab, and, as he writes, it was the year 332/943 A.D., the Oases were independent, ruled by a certain Abd al-Malik ibn Marwan of the Berber Lawata tribe, but of Omayyad-Marwanide orientation. As we learn from later sources the independence was of long duration with several rulers in succession, but was rather relative: the rulers, sometimes called "kings" were vassals of Egyptian governors. The latitude of their independence must have however been considerable since, as we are told by al-Mas'udi, the master of the Oases had an army of many thousands horse riders. Such a mobile force in the desert must have been very useful for the defence of the Nile Valley against nomads.

This army evidently did not save the Oases themselves. About the same time, as al-Maqrizi, a 15-th century historian and topographer, informs us, 
a powerful army under the king of Nubia raided the Oases. Many people were killed, many others taken prisoner, and certainly material losses were considerable. The reason for the attack is not clear. Could it be in connection with the persecution of the monks to which the above-quoted alIstakhri might have alluded? It would have been not the first intervention of the kings of Nubia in defence of the Coptic Church in Egypt. In the year $747 / 8$, for instance, the Nubian army in defence of the Patriarch persecuted by the Islamic authorities ventured as far as al-Fustat, the Egyptian capital (Patrologia Orientalis V).

It is not known when the Oases returned under the direct rule of the Egyptian authorities. Probably it had taken place under the early Fatimid caliphs, originally very powerful rulers having strong links with North Africa and consequently with the Sahara too. At any rate, we hear of the Governor of the Bahnasa Oasis in the caliph al-Hafiz' times (1130-1149; Abu Salih, transl. Evetts 1895).

Farafra in later times was never cited by its name, at least not until the 19 th century. The Oases, on the other hand, with their division into three administrative units (in Arabic kur, sing. kura) usually called Bahnasiya or Khass (later Baharia), Dakhla and Kharga, with some variants of their names, were often mentioned and presented as flourishing regions with numerous villages and prosperous agriculture. Farafra as in the earlier period was evidently listed together with Dakhla. An important, although indirect, prove is given by Ibn Duqmaq (14th c.), the only writer who gives figures of taxes paid yearly by the particular kuras. For the oasite ones he gives: Bahnasa $-13,000$ dinars, Kharga $-12,000$ dinars and Dakhla 29,000 dinars (!). Since there is no mention of Farafra, and the sum collected from Dakhla exceeds the total of Bahnasa and Kharga, the explanation must be not economic, for there is no reason for this, but simply that administratively Farafra was included in the kura of Dakhla.

In the Mamluk Period (1250-1517), the last of Egyptian independence, before the modern political processes took place, the Oases, notwithstanding the information (probably of earlier date) of their relative prosperity, commence to decline. Again, the oasite region gains relative independence from the central Mamluk governing bodies of Cairo and is ruled by feudal lords. The allusions of al-Qalkashandi, a great Egyptian encyclopedist of the early 15th century (Amiriya edition), indicate ruthless exploitation and oppressive rule of the local masters. This in all probability and not other reasons must have brought decline of the productive capacities of the region and gradual depopulation. At Farafra the process have been hastened by the frequent incursions of the nomads not only from the Libyan Desert but also by the Arab tribes from the Mariout district and other northern lands. The Ottoman Turks who took over Egypt from the Mamluks in the early 16 th century, have probably left the Oases to their fate and Farafra was the foremost to be abandoned. If not for the remnants 
of a fortress of uncertain date which gave its name to the late settlement Qasr Farafra - and which gave shelter to the meagre population that survived there, it would have been a desert by now. Only the extraordinary varied assortment of useful plants, in particular fruit trees and vegetables praised by 19th-century travellers, bear witness to the rich agricultural traditions, and the local, already disappearing folklore tells of its long past history.

For the technical reasons the scientific transcription of Arabic names (diacritical points etc.) could not be introduced. 